\title{
Fortellinger i nordnorsk minoritetshistorie
}

\author{
Av Teemu Ryymin og Jukka Nyyssönen
}

\section{Ingress:}

Den norske historieskrivingen om samene og kvenene har fra 1970-tallet av vart preget av skiftende måter å fortelle om disse store nordlige etniske minoritetenes historie. I denne artikkelen diskuterer vi hvilke fortellingsmфnstre som har preget den norske historieskrivingen om samene og kvenene, og hva slags betydning de ulike fortellingsmønstrene kan sies å ha hatt. $V i$ identifiserer tre fortellingsmфnstre som grovt sagt har dominert hvert sitt tiår: Synliggjфringshistorier, fortellinger om assimilering og fortellinger om agens. Disse fortellingene har imidlertid ikke avlфst hverandre suksessivt, men er blitt etablert lag på lag. Slik sett har den nordnorske minoritetshistorien blitt stadig mer mangfoldig.

Samisk og kvensk historie ble for alvor etablert som et akademisk felt i Norge på 1970- og 1980tallet. Selv om forskningsinteressen for disse grupper har lange røtter, var det frem til da språk-, kultur- og samfunnsforskere - og sakprosaforfattere - som dominerte fremstillingen av deres historie. ${ }^{1}$ At historikerne på 1970-tallet i økende grad begynte å skrive om samer og kveners historie, hang dels sammen med inspirasjon fra nye sosialhistoriske perspektiver som begynte å gjøre seg gjeldende på denne tiden, med ønsker om å komplettere historien med emner som "mennesker uten makt" og å se samfunnet "nedenfra" i sentrum. Samfunnsviternes økende interesse for minoritetene i nord bidro også, sammen med bredere politiske forhold som den internasjonale avkoloniseringen, samenes etnopolitiske mobilisering, og offentlig vilje til å endre den tidligere assimileringspolitikken. Åpningen av Universitetet i Troms $\varnothing$ i 1972, som allment bidro til "den samiske kulturreisinga", samt etableringen av rettshistorisk forskning ved Nordisk Samisk Institutt, åpnet i 1973, bidro også til å rette historikernes oppmerksomhet mot samene og

\footnotetext{
${ }^{1}$ L. I. Hansen og B. Olsen, Samenes historie fram til 1750, Oslo 2004, 10 ff; E. Niemi, History of minorities: The Sami and the Kvens, i W. H. Hubbard et al. (red.), Making a historical culture. Historiography in Norway, Oslo 1995; E. Niemi, Kvenforskningen: Et forskningshistorisk perspektiv, i T. Ryymin og E. Karikoski (red.), Kvensk forskning. Rapport fra kvenseminaret ved Universitetet $i$ Troms $\phi$, mai 2000, Troms $\varnothing 2001$.
} 
kvenene. ${ }^{2}$ Fra 1981 styrket Norges almenvitenskapelige forskningsråds tiårige "Program for samisk og kvensk språk, historie og kultur" forskningen om de nordlige minoriteter. ${ }^{3}$

Slike institusjonelle forholds og historikernes ideologiske og politiske tilknytningers påvirkning på historiske tekster står gjerne sentralt i historiografiske analyser som er innrettet etter den britiske historikeren Edward Hallett Carrs spissformulering "[s]tudy the historian before you begin to study the facts". Historiografiske oversikter er ofte også opptatt av å presentere hvordan historikere har behandlet sentrale tema på bestemte felt, av å dele forskningshistorien $\mathrm{i}$ faser ut fra forskningens mengde, og å diskutere forskningens effekter. Når det gjelder kvensk og samisk historieskriving, har den norske historikeren Einar Niemi skissert 1970-tallet som en "runway-fase" for kvenforskningens del, etterfulgt av en "take-off-fase" i 1980-årene og en mer uoversiktlig og pluralistisk 1990-tallsfase. ${ }^{5}$ Tematisk konsentrerte historikerne i 1970-årene seg særlig om demografiske forhold og migrasjon, på 1980- og 1990-tallet om offentlig minoritetspolitikk og minoritetenes etnopolitiske mobilisering; i samisk historie var næringshistorie (reindrift og sjøsamisk tilpasning) og særlig rettighetsproblematikk knyttet til bruken av land og vann viktige tema. ${ }^{6}$ Man kan også konstatere at minoritetshistorie, til tross for at feltet ikke er særlig voluminøst, har hatt effekter på flere områder: Fra 1980-årene har for eksempel historien om etniske relasjoner blitt et uomgjengelig tema i nordnorsk lokalhistorie. Fremstillinger av samenes og kvenenes historie har også spilt en rolle i offentlig forvaltning og politikk, for eksempel i tilknytning til Samerettsutvalgets arbeid og i prosessen som førte til en offisiell norsk anerkjennelse av kvenenes status som en nasjonal minoritet. Dels har historisk forskning vært med på å legitimere slike politiske vedtak, dels har de politiske prosessene generert ny forskning om minoritetene. ${ }^{7}$ Minoritetshistoriske arbeid har også preget innholdet $\mathrm{i}$ minoritetenes politiske mobilisering - eksempler på det er rehabiliteringen av etnonymet "kven" og historisk legitimerte krav om rettigheter for eksempel til egen ressursforvaltning. ${ }^{8}$

\footnotetext{
${ }^{2}$ Hansen og Olsen 2004: 10 ff; N. Fulsås, Universitetet $i$ Troms $\varnothing 25$ år, Tromsø 1995: 305.

${ }^{3}$ Jf. N. Bjørgo, Oppsummerende notat til Rådet for humanistisk forskning om 'Fagleg utviklingsprogram for samisk og kvensk: Språk, historie og kultur.' (A.99.00.114), Troms $\varnothing 1980: 11-13$.

${ }^{4}$ E. H. Carr, What is history?, Basingstoke 2001: 17 [opprinnelig publisert 1961].

${ }^{5}$ Niemi 2001: 17-22.

${ }^{6}$ Oversikter over minoritetshistorisk forskning i Norge, se Niemi 1995 og 2001; H. Minde, Samenes historie som etterkrigshistorisk forskningsfelt, revidert versjon av manuskript, LOS-senter notat 92/28, 1992.

${ }^{7}$ Jf. NOU 1984:18 Om samenes rettsstilling: 402-410; NOU 1997:4 Naturgrunnlaget for samisk kultur: 579; St.meld. nr. 15 (2000-2001) Nasjonale minoritetar i Noreg - Om statleg politikk overfor jødar, kvener, rom, romanifolket og skogfinnar: $28-33$.

${ }^{8}$ Jf. E. Niemi, Kven - et omdiskutert begrep, Varanger Årbok 1991: 119-137: Jf. B. Evjen, Samene sin plass i nordnorsk lokalhistorie, Speculum Borealia 2004, 4: passim.
} 
Det minoritetshistoriske feltet har altså i Norge stått i krysspunktet mellom vitenskaps- og samfunnsutvikling, fag og politikk. I denne artikkelen ønsker vi å bidra med et annet historiografisk perspektiv ved å diskutere måtene minoritetshistorie har blitt skrevet, gjennom en analyse av fortellinger som har preget den norske historieskrivingen om samer og kvener fra 1970-tallet av. Avslutningsvis vil vi også kort kontrastere den norske minoritetshistorieskrivingen med tilsvarende historiografiske felt i Australia og USA.

Metodisk vil vi legge vekt på ulike fortellings- eller narrative mønstre som ligger til grunn for historikernes fremstillinger, og som kan finnes igjen i flere tekster. Med fortelling sikter vi her til de historiske teksters ordning: Historiske tekster, der elementene i fortellingen er kronologisk ordnet, har gjerne også en konfigurativ dimensjon som anviser hvordan disse elementene skal ordnes innbyrdes i forhold til hverandre. ${ }^{9}$ En slik konfigurasjon bidrar med et ordnende grep som gir elementene og helheten - altså fortellingen - mening. Dette skjer ved at elementene eller hendelsene organiseres $\mathrm{i}$ en sammenheng gjennom etableringen av et plott, det vil si en sammenbindende idé, perspektiv eller synsmåte som preger utvelgelsen av de relevante forhold som skal til for å fortelle den aktuelle historien. ${ }^{10}$

Eksempler på slike plott eller synsmåter i vår sammenheng er synliggjøring historieskriving som viser frem bestemte folkegrupper eller kategoriers historie; fortellinger om assimilering som vektlegger hvordan samer og kvener er blitt behandlet gjennom fornorskningspolitikken og/eller moderniseringen av Nord-Norge, og agens-fortellinger som har som sitt fremste mål å beskrive hvordan bestemte folkegrupper handlet i fortiden.

Slike sammenbindende synsmåter blir gjerne lagt til grunn for svært ulike historiske tekster, men de kan likevel gjenkjennes i mange tekster nærmest som sjangertrekk eller som markører på tekstenes tilhørighet på et bestemt historiografisk felt, som fortellingsmønstre eller tradisjoner. De enkelte historiske tekster er naturligvis mangefasetterte, og elementer som kan inngå i fortellinger som bygger for eksempel på et synliggjørings- eller assimileringsplott kan gjenfinnes i mange tekster. Det kan likevel være nyttig å skissere slike overordnede fortellingsmønstre for å få grep om noen hovedtendenser i norsk historieskriving om de nordlige minoritetene - tendenser som ikke fremtrer like tydelig ut fra andre historiografiske perspektiver.

\footnotetext{
${ }^{9}$ P. Ricoeur, Time and narrative, 1, Chicago 1984: 67.

${ }^{10}$ P. Veyne, Writing history. Essay on epistemology, Middletown 1984: 32-34, 87.
} 
Fortellingsmønstre kan ha ulike funksjoner i skiftende sammenhenger. Allment mobiliserer fortidsfortellinger erfaringer av fortid slik at nåtiden blir forståelig, og de muliggjør forventninger til fremtiden. De kan skape kontinuitet som gjør erfaringene av fortiden relevante for nåtiden, og de kan være med på å etablere og stabilisere ulike identiteter. Den tyske historikeren Jörn Rüsen fremhever allment at historiske fortellingers funksjon på ulike måter er å ordne det praktiske livet i tid. ${ }^{11}$ I denne sammenheng kan "det praktiske livet” konkretiseres til å bety at fortellingsmønstrene i minoritetshistoriske tekster kan ha ulike politiske, men også historiefaglige funksjoner. Som blant annet historikerne Michael Bravo og Sverker Sörlin har påpekt, kan det i tekster om for eksempel nordlige vitenskapelige ekspedisjoner finnes nasjonale "mesterfortellinger" om modernisering og fremskritt som legitimerer statens tilstedeværelse i nordlige periferier. Minoritetshistoriske fortellinger har ofte posisjonert seg i opposisjon til disse som motnarrativer som tar sikte på å delegitimere statlig hegemoni og legitimere andre identitetskollektivers historiske tilstedeværelse. Slike motnarrativer kan sees på som "provosert" - men også inspirert av de dominante mesterfortellinger. ${ }^{12}$ I tillegg til disse politiske funksjoner kan slike fortellinger samtidig også prege historikernes utvelgelse og tilsvarende utelatelse av forskningsobjekter: Nasjonale mesterfortellinger ga lite rom for etnisk mangfold i fortiden, mens historieskriving som baserer seg på etnisitet som den avgjørende historiske kategorien kan stå i fare for å neglisjere for eksempel klasse og kjønn.

Materialet som det følgende er basert på, består av et utvalg av tekster skrevet av historikere og i noen tilfeller samfunnsvitere i hovedsak ved norske høyere læresteder. Tekstene er fordelt på ulike sjangre - hovedfags- og masteroppgaver, doktoravhandlinger, kortere vitenskapelige og populærvitenskapelige artikler og større monografier og samleverk. Tekstutvalget er gjort ut fra vår kjennskap til feltet, slik at vi har tatt for oss tekster som vi mener har vært av særlig betydning for historieskriving om samer og kvener - for den samiske historiens del, verk som vi anser som nøkkeltekster angående samisk etnopolitikk. Vi har valgt å begrense tekstutvalget for samisk histories del til studier om samenes etnopolitiske mobilisering,

\footnotetext{
${ }^{11}$ J. Rüsen, History. Narration - Interpretation - Orientation, New York/Oxford 2005: 9-19.

${ }^{12}$ M. Bravo og S. Sörlin, Narrative and Practice - an Introduction, i M. Bravo og S. Sörlin (red.), Narrating the Arctic. A Cultural History of Nordic Scientific Practices, Canton, MA 2002: 4, 12, 19-21; E. Lund, Fortellinger om Norge og norskhet gjennom bilder, i R. Arntzen, R. Danielsen og K. Lyhmann (red.), Plutselig ble det en fortelling. Om fortellinger og forteller, Halden 2001: 110 et passim; S. Sörlin, Rituals and Resources of Natural History, The North and the Arctic in Swedish Scientific Nationalism, i M. Bravo og S. Sörlin (red.), Narrating the Arctic, A Cultural History of Nordic Scientific Practices, Canton, MA 2002: 74-75; K. Thisj, The Metaphor of a Master: 'Narrative Hierarchy' in National Historical Cultures of Europe, i S. Berger og C. Lorenz (red.), The Contested Nation. Ethnicity, Class, Religion and Gender in National Histories, London 2008: 60.
} 
mens tekstene om kvenene - som er generelt langt færre enn de om samisk historie - omfatter flere tema. Tekstutvalget kan naturligvis kritiseres for ikke å være uttømmende, men vi mener likevel det avspeiler hovedstrømninger innen norsk historieskriving om samer og kvener.

De aktuelle tekstene er først og fremst lest med blikk for de konfigurative elementene som binder sammen og gir mening til helheten av historiske fakta, begivenheter og strukturer som tekstene refererer til, samt funksjonene disse tekstene kan sies å ha hatt på ulike felt. Vi har ikke $\emptyset$ nsket å vurdere gehalten eller "riktigheten" i de enkelte historiske arbeid. Men samtidig har vi også et kritisk-konstruktivt anliggende, ved at vi ønsker å peke på noen muligheter til å videreutvikle historieskrivingen om de nordlige minoriteter.

\section{Fra synliggjøringen av kvenenes spor ...}

Selv om 1970-årene kan tidfestes som en periode der historieskrivingen om de nordlige minoritetene nærmest tok av, i tråd med Einar Niemis vurdering, var utgangspunktene for samisk og kvensk historieskriving noe ulike. Mens den samiske historieskrivingen i 1970-årene ble skrevet inn i - eller snarere imot - en allerede veletablert tradisjon hvor det eksisterte tydelige stereotype fortellinger om samenes fortid, hadde historieskrivingen om kvenene et noe annet utgangspunkt: Nemlig en lang periode av nær taushet om kvenene. ${ }^{13}$ Dermed ble det å vise frem at kvenene hadde en historie sentralt.

Et slikt siktemål for historisk forskning stod helt sentralt i den samtidige sosialhistorien, som den norske minoritetshistorieskrivingen på mange måter kan forstås som en subdisiplin av. Dette reflekteres også i de emnene den tidlige historieforskningen omkring kvenske forhold satte i fokus, nemlig migrasjon og demografiske forhold. ${ }^{14}$ Man kan også se forbindelseslinjer mellom minoritetsforskningen og sosialhistorien på et mer grunnleggende plan, nemlig i forhold til forskningens kulturpolitiske oppgaver. Sosialhistorikeren Edvard Bull den yngres diktum om at alle har "rett til en fortid" kan i korthet illustrere en forskningsetos som ble gjort gjeldende innenfor sosialhistorien, i Norge og andre steder på 1970-tallet. ${ }^{15}$ Denne holdningen var i

\footnotetext{
${ }^{13}$ Niemi 1995: 339.

14 Jf. Niemi 2001: 18. Om 1970-årenes norske sosialhistorie, se for eksempel J. E. Myhre, Social History, i W. H. Hubbard et al. (red.), Making a Historical Culture. Historiography in Norway, Oslo 1995: 224-239.

${ }^{15}$ Se for eksempel E. Bull, Historisk vitenskap foran 1970-årene. Tale ved hundreårsjubileet for Den norske historiske forening, 9. januar 1970, Historisk tidsskrift 1970, 49: 245-259; E. Bull, Retten til en fortid. Sosialhistoriske artikler, Oslo 1981. Jf. E. Niemi, Det nordnorske historieseminaret: Service og dannelse. Jubileumsforedrag, i F. Fagertun et al. (red.), Det farefulle nord. Trusler og trusseloppfatninger knyttet til NordNorge gjennom tusen år, Tromsø 2001: 176-178.
} 
opposisjon til det man oppfattet som eldre, statssentrert politisk historie, som mer eller mindre bevisst ekskluderte de brede lag fra forskningens fokus og dermed historien. Den nye sosialhistoriske etos betonet at ikke-privilegerte eller undertrykte grupper, som hadde vært utelatt eller marginalisert i tidligere historieskriving - det være seg kvinner, arbeiderklassen eller etniske minoriteter - nå skulle få sin historie skrevet, på sine egne premisser og fra deres eget perspektiv. ${ }^{16}$

Synliggjøring preget de hovedfagsoppgaver i historie som på mange måter etablerte kvenene som et objekt for akademisk norsk historieskriving på 1970-tallet: Hovedfagsoppgavene til Einar Niemi (1972) om den finske flyttingen til Vadsø mellom 1845 og 1885, Terje Henninen (1972) om den kvenske innvandringen til Alta på 1700-tallet og Geir Haukedal (1980) om kveninnvandringen til Nord-Troms og Vest-Finnmark mellom 1700 og 1865, bygde alle på en grunnfortelling som viste kvenenes spor i historien. Gjennom registrering, kartlegging og forklaring av migrasjonen, basert på folketellinger, skattemanntall, kirkebøker og litteratur, synliggjorde disse tekstene kvenenes - eller finnene som de gjerne ble benevnt på 1970-tallet vandring fra økonomisk og sosialt vanskelige kår i Finland og Nord-Sverige til en pionergjerning ved Ishavskysten. Kvenene ble bokstavelig talt vist frem i historien gjennom analyser av innvandringens forløp og granskinger av hvem i skattemanntall, folketellinger og matrikler som kunne sies å være kvener: Konkret kunne dette komme til uttrykk blant annet gjennom opplistinger over "Familier i Alta som er kvenske ifølge folketellingen 1801". ${ }^{17}$

Det grunnleggende synliggjøringsplottet hadde flere funksjoner. Gjennom å vise hvem som historisk hadde tilhørt bestemte etniske kategorier, var synliggjøring av selve kategoriene den mest manifeste av disse. Synliggjøringen - særlig i form av forfatternes vurdering av innvandringens konsekvenser i de aktuelle lokalsamfunn - fungerte også som en slags moralsk rehabilitering av kvenene, skrevet i opposisjon til tidligere fremstillinger av kvenene som enten hadde fortiet gruppen eller fremstilt den i negative termer - for eksempel i Niemis diskusjon av utvandrernes forhold til loven i hjemlandet. ${ }^{18}$ Fortellingen om (det tidligere undervurderte)

\footnotetext{
${ }^{16}$ B. Odén, Den 'osynliga historien', i B. Wåhlin og B. Qviller (red.), Studier i historisk metode 17. Usynlig historie. Foredrag fra den 17. Nordiske fagkonferansen for historisk metodelare i Tranum Klit 19.-23. mai 1981, Oslo 1983: 14-15; P. Maurseth, Mellom Seip og Bull. Tilbakeblikk på en jubileumsdebatt, i P. Fuglum og J. Simensen (red.), Historie nedenfra. Festskrift til Edvard Bull på 70-årsdagen, Oslo 1984: 148; Myhre 1995: 226, 239; K. Kjeldstadli, Fortida er ikke hva den en gang var. En innføring i historiefaget, Oslo 1999: 82.

${ }^{17}$ T. Henninen, Den kvenske innvandring til Alta på 1700-tallet, upublisert hovedfagsoppgave i historie, Universitetet i Trondheim 1972: 109-121.

${ }^{18}$ E. Niemi, Oppbrudd og tilpassing. Den finske flyttingen til Vadsø 1845-1885, Vadsø 1977: 119-121.
} 
kvenske pionerbidrag til Nord-Norges utvikling var fremtredende: Ifølge Henninen bidro kvenene til å "befolke og utbygge" deler av Finnmark, kvenene "gjorde en innsats" på mange næringsfelt, og "viste at jordbruk gikk an også i Finnmark". ${ }^{19}$ Ifølge Niemi syntes det klart at innvandrerne fylte et behov for arbeidskraft i det ekspanderende Vads $\varnothing$, og at det syntes

å være hevet over tvil at det var de finske innvandrerne som bidro mest til et gjennombrudd for et relativt utviklet jordbruk i 'vårt' område, og dermed ble næringsgrunnlaget gjort bredere og mer variert. De ressursene som fantes på dette området, var bare i begrenset grad blitt utnyttet tidligere. ${ }^{20}$

Nå fremhevet man altså kvenenes arbeidsomhet og egenskaper som nyryddere i positive ordelag. Selve beskrivelsen av kvenenes vandring fra vanskelige kår til bedre forhold hvor de positive egenskapene kom til uttrykk, hadde en slik oppvurderende dimensjon. Synliggjøringsfortellingene kunne altså fungere som en form for motnarrativer, selv om denne funksjonen var tydeligere i tekstene om samisk historie (se under). Slike motnarrativer, som løftet frem en tidligere usynliggjort kategori og siktet på å endre vurderingen av individer innskrevet som hjemmehørende i slike kategorier, kan sees på som en parallell til kvinnehistorisk forskning på 1970-tallet. ${ }^{21}$

Den positive bedømmingen av kvenenes bidrag i Nord-Norge var imidlertid ikke unison: Geir Haukedal, den eneste som gjorde et større poeng ut av relasjonen mellom kvenene og samene i sin oppgave, understreket i 1980 i stedet at de første kvenene som innvandret til Kautokeino, Tanadalen og Alta bosatte seg "uten at det ser ut til at de har hatt hensyn til at det allerede var en samisk befolkning i området. Hverken samenes krav på enerett til sine gamle bosettingsområder, eller de dertil hørende ressurser, ser ut til å ha hatt innvirkning på kvenenes valg av boplasser eller deres ressursutnytting." ${ }^{22}$ Her kan vi altså se konturene av at forskningen legger vekt på et konfliktforhold mellom minoritetene - men generelt var det staten som ble presentert som kvenenes "motpart" i 1980-årene.

\section{... til fornorskningspolitikkens slagskygge}

Relasjonen mellom kvenene og den norske staten fikk relativt liten plass i 1970-tallstekstene. Dette endret seg ettertrykkelig i det påfølgende tiåret, da fortellingen om kvenenes og samenes

\footnotetext{
${ }^{19}$ Henninen 1972: 145.

${ }^{20}$ Niemi 1977: 164.

${ }^{21}$ Jf. I. Blom, Women's history, i W. H. Hubbard et al. (red.), Making a historical culture. Historiography in Norway, Oslo 1995: 290-291.

${ }^{22}$ G. Haukedal, Den kvenske innvandring til Nord-Troms og Vest-Finnmark 1700-1865, upublisert hovedfagsopgave i historie, Universitetet i Bergen 1980: 109.
} 
ublide skjebne i slagskyggen av fornorskningspolitikken, og den fåfengte motstanden mot assimileringspolitikken, for alvor ble etablert i norsk historieskriving. Dette skjedde gjennom en supplering av det tidligere fokuset på migrasjon med studier av fornorskningspolitikkens utforming og etnopolitisk mobilisering. Temaene var ikke nye; det nye var at historikere i 1980årene aktivt skrev seg inn på et felt som tidligere hadde vært dominert av pedagoger og sosialantropologer, dels i opposisjon og dels i tilslutning til samfunnsviterne. ${ }^{23}$ Historieskrivingen om både samer og kvener fra 1980-årene var opptatt av den asymmetriske maktrelasjonen mellom de nordnorske minoritetene og storsamfunnets representanter.

Dreiningen i historikernes interesse i denne retning ble i 1987 forklart med henvisning til "vilje til tverrfaglig debatt og tilnærming, og sterkere vektlegging av vitenskapsteori og forskningsmetode." ${ }^{24}$ Tverrfaglig teori og metode kunne blant annet dreie seg om normative posisjoner om hva slags historier man burde skrive - og hvorfor: Sosialantropologen Ivar Bjørklund fremhevet i 1980 i forbindelse med en diskusjon om lokalhistorier i Nord-Norge at "en fremstilling av fornorskningsprosessen og dens følger" for de fleste i Nord-Norge ville fremstå som "en mulighet til å forstå sitt liv og sin samtid bedre og kanskje være en spore til oppvurdering og organisering omkring en felles samisk eller kvænsk bakgrunn." 25 Historikeren Helge Salvesen påtalte samme år det paradoksale $\mathrm{i}$ at for eksempel samisk historie $\mathrm{i}$ hovedsak ble skrevet av ikke-samer for ikke-samer - underforstått at samene selv måtte slippe til i skrivingen av sin egen historie. Utgangspunktet for samehistorisk forskning burde ifølge Salvesen ligge i et "ønske om en utbygging og forsterking av samenes bevissthet om sitt eget kulturgrunnlag, sin egen identitet." ${ }^{26}$ Han vektla implisitt også at god forskning skulle styrke samenes rettigheter, gjennom å kritisere tidligere forskning for å ha "virket til å svekke samenes rettigheter". ${ }^{27}$ Her ser vi med andre ord en forskyving i historikernes erklærte intensjoner i retning av (etnisk) frigjøring; forskningens funksjon skulle være å legge til rette for å skape rettferd, gjennom å vise historisk urett og ved å mobilisere til politisk handling. Med andre ord skulle forskningens funksjon dreies fra synliggjøring til emansipasjon. Hvordan reflektertes dette i historietekstenes fortellinger?

\footnotetext{
${ }^{23}$ Jf. E. Niemi og H. Salvesen, Samene og kvenene/finnene i minoritetspolitisk perspektiv, i G. Karlsson (red.), Nationale og etniske minoriteter i Norden i 1800- og 1900-tallet. Rapporter til den XX nordiske historikerkongress, bd. 2, Reykjavik 1987: 69.

${ }^{24}$ Niemi og Salvesen 1987: 69.

${ }^{25}$ I. Bjørklund, Etnisk mangfold, et problem i bygdeboka, Heimen 1980, XVIII: 471.

${ }^{26}$ H. Salvesen, Tendenser i den historiske sameforskning - med særlig vekt på politikk og forskning, Scandia 1980, 1: 42 .

${ }^{27}$ Salvesen 1980: 38-39.
} 
Historikerne Knut Einar Eriksen og Einar Niemis Den finske fare. Sikkerhetsproblemer og minoritetspolitikk $i$ nord 1860-1940 fra 1981, en av denne periodens mest sentrale minoritetshistoriske analyser, presenterte en - sett i ettertid - meget innflytelsesrik fortelling om de norske myndighetenes hårdhendte behandling av samene og kvenene $\mathrm{i}$ form av et assimileringsplott: Den opprinnelig aksepterende holdningen til innvandrerne på 1700- og første tiårene av 1800-tallet, generert blant annet av kvenenes agrare egenskaper og arbeidsomhet, endret seg gjennom en omdefinering av kvenene som et nasjonalt sikkerhetsproblem i 1860-årene, til en målbevisst fornorskningspolitikk på en rekke samfunnsområder. Politikken rettet seg mot både samer og kvener, men virkemidlene overfor kvenene var sterkere og mer konsekvente, og kvenene ble hardest rammet av assimileringspolitikken. ${ }^{28}$ At samene effektivt bevarte sin "kulturelle integritet" til tross for fornorskningen hang ifølge Den finske fare sammen med deres næringsutøvelse, mens kvenenes status som innflyttere bidro til en "egenoppfatning blant kvenene om at de ikke hadde rett til å kreve noe som ville kunne bidra til bevaring av deres kulturelle integritet." Aksept av assimilasjonen syntes for mange kvener å "være den eneste naturlige skjebne i det nye hjemland”, og dessuten et middel til å oppnå status og nasjonal pålitelighet. ${ }^{29}$ Dette var i mindre grad tilfellet for samene, som for $\varnothing$ vrig utviklet sine organisasjoner i mellomkrigstiden til dels uten at storsamfunnet la hindringer i veien for dem. Kvensk mobilisering - i den grad der fantes noe slikt - ble "motarbeidet og overvåket". ${ }^{30}$

Generelt var det analytiske fokuset i Den finske fare og andre arbeid som delte assimileringsplottet egentlig ikke på selve minoritetene, men på de som handlet overfor samene og kvenene; minoritetenes egen agens var kun i liten grad til stede i disse verk. Snarere ble minoritetene ofte fremstilt som ofre - det vil si som objekter som andre handler i forhold til. ${ }^{31}$ I Den finske fare ble minoritetenes offerposisjon fremstilt som nokså total:

Ett spørsmål er jo hvilke muligheter minoritetene egentlig hadde for å reise noen motstand. De hadde i utgangspunktet alle odds mot seg i eventuelle fors $\varnothing \mathrm{k}$ på å bli hørt i storsamfunnet: Språkproblemer, mangel på organisasjon, lav sosial status og ofte en egenoppfatning preget av samfunnets opplysningsvirksomhet. Da den samiske reising kom, måtte det egentlig overraske. ${ }^{32}$

\footnotetext{
${ }^{28}$ K. E. Eriksen og E. Niemi, Den finske fare. Sikkerhetsproblemer og minoritetspolitikk i nord 1860-1940, Oslo 1981: 331

${ }^{29}$ Eriksen og Niemi 1981: 332.

${ }^{30}$ Eriksen og Niemi 1981: 332.

${ }^{31}$ Denne forståelsen av "offer" bygger på C. Gilligan, Constant Crisis/Permanent Process: Diminished Agency and Weak Structures in the Northern Ireland Peace Process, The Global Review of Ethnopolitics, 2003, 3, 1: 30.

${ }^{32}$ Eriksen og Niemi 1981: 338.
} 
Det kostet å opponere, til og med stortingsrepresentantene samen Isak Saba og kvenen Aksel Konrad Mikkola "ble nærmest tiet i hjel i Stortinget" og i sitt eget parti, Arbeiderpartiet. ${ }^{33}$ Det viktigste resultatet av fornorskningen var, ifølge Den finske fare, de negative virkningene på individets selvoppfatning og selvopplevelse: "[U]tviklingen av tap av aktelse for egen identitet og identitetsfornektelse [var] nærliggende i slagskyggen av fornorskingspolitikken." ${ }^{34}$ Minoritetenes handlinger - som bytte av etnisitet - ble tolket som respons på presset utenfra: "Det kulturelle press resulterte ofte $\mathrm{i}$ at bytte av etnisitet ble søkt som en utvei. Beherskelse av norsk, annamming av norske klær og norske vaner samt skoleflinkhet gav sjøltillit og resulterte i akseptasjon av storsamfunnet." 35

Denne fortellingen fortjener en såpass detaljert gjennomgang nettopp fordi den var velformulert, grundig dokumentert og ikke minst gjennomslagskraftig. ${ }^{36}$ I mange senere tekster som dreier seg om de nordlige minoritetene, og nordnorsk historie mer allment, er den reprodusert som et selvsagt utgangspunkt som annen forskning kan komplettere og/eller utvide. ${ }^{37}$ Men i tekster som deler det overordnede assimileringsplottet kan offerposisjonen som samene og/eller kvenene blir plassert i, bli nokså dominerende. ${ }^{38}$ Den sterke posisjonen til assimileringsfortellingen om samenes og kvenenes historie kan ha vært med på å rette forskernes oppmerksomhet mot forhold i fortiden som i utgangspunktet bekrefter selve fortellingen om assimilering - og samtidig bort fra forhold som fremstår som mindre relevante i forhold til denne fortellingens plott. ${ }^{39}$ Det er $\mathrm{i}$ alle fall en mulig forklaring på at arkivmateriale som kunne ha bidratt til å nyansere fremstillingene om fornorskningspolitikkens dominans - og samenes og kvenenes passive offerposisjon - har i stor grad unngått historikernes oppmerksomhet. Som litteraturviteren og arkivforskeren Kaisa Maliniemi nylig har vist, finnes det hundretalls dokumenter på samisk og kvensk i Kistrand (Porsanger) kommunearkiv fra perioden 1867-1911 som viser at minoritetene aktivt deltok i kommuneforvaltningen - og at deres språk ble brukt i

\footnotetext{
${ }^{33}$ Eriksen og Niemi 1981: 341.

${ }^{34}$ Eriksen og Niemi 1981: 343.

${ }^{35}$ Eriksen og Niemi 1981: 343.

${ }^{36}$ Jf. T. Ryymin og K. Maliniemi, Nytt lys på fornorskningspolitikken? Sentrale direktiver og lokal virkelighet, i A.R. Lindgren et al. (red.), Kvener i fortid og nåtid. Rapport fra seminaret Kvener og skogfinner i fortid og nåtid, Troms $\varnothing$ november 2007, Troms $\varnothing$ 2009: 134-135.

${ }^{37}$ Se for eksempel T. Ryymin, 'De nordligste finner'. Fremstillingen av kvenene i den finske littercere offentligheten 1800-1939, dr.art.-avhandling, Universitetet i Tromsø 2003; T. Ryymin, Smitte, språk og kultur.

Tuberkulosearbeidet i Finnmark, Oslo 2009.

${ }^{38}$ Se for eksempel T. Bull og H. Gaski, Fornorskningspolitikk og språkundertrykking, i E. A. Drivenes et al. (red.), Nordnorsk kulturhistorie 2. Det mangfoldige folket, Oslo 1994: 246-258.

39 Jf. Ryymin og Maliniemi 2009: 131-144; Veyne 1984: 32-33.
} 
den kommunale virksomheten, i tillegg til norsk. ${ }^{40}$ Dette arkivmaterialet, som har vært tilgjengelig for alle, er ikke brukt for eksempel i Porsanger bygdebok, som legger vekt på den omseggripende fornorskningen i området i denne perioden. ${ }^{41}$

Mens synliggjøringsfortellingen primært vektla å presentere minoritetenes historiske tilstedeværelse, forklarte assimileringsfortellingen hvorfor minoritetene var blitt mindre synlige assimilert - som et resultat av press utenfra. I den grad samenes og kvenenes egne handlingsmønstre og valg ble tematisert, skjedde det gjerne $i$ form av en etnisk motstandsfortelling: Det ytre kulturelle presset resulterte i "etnisk reaksjon og politisk mobilisering". 42 Andre mulige handlingsalternativer synes å ha fremstått som problematiske, og i mange tekster synes det å ligge en forventning om at samene og kvenene burde ha mobilisert etnisk mot fornorskningspresset. I den grad samer - og kvener - handlet på måter som ikke lett lar seg innordne $\mathrm{i}$ en etnisk motstandsfortelling, tolket man dette gjerne som et utslag av fornorskningspolitikken og etnisk selvfornektelse. Særlig tydelig er dette i diskusjonene av reaksjonene til den såkalte Samekomiteens innstilling av 1959. Denne komiteen, nedsatt av Stortinget til å utrede prinsipielle sider ved samfunnsspørsmål vedrørende samene, fremmet en samepolitikk som brøt med den tidligere assimileringslinjen. Nå skulle staten fremme og styrke den samiske kulturen gjennom økonomiske og kulturelle tiltak, blant annet ved å styrke opplæring i samisk språk og kultur i skoleverket. ${ }^{43}$ Niemi og Salvesen beskrev den kraftige lokale motstanden mot komiteens innstilling slik i 1987:

I lokalmiljøene var motstanden mot Samekomitéens innstilling dels ekstremt sterk, også blant mange samer. Rasjonelle økonomiske og sosiale argumenter ble anvendt mot innstillingen med utgangspunkt i den velferdsstatsideologi som ble utviklet $\mathrm{i}$ gjenreisningstida etter 2 . verdenskrig. Virkningene av fornorskningspolitikken kan leses i disse holdningene, som i ikke liten grad representerte nedvurdering av det samiske og etnisk sjølfornekting. Den økonomiske vekst og den sosiale utjevningspolitikk etter krigen bidro også i seg sjøl til avfokusering av samepolitiske problemstillinger i lokalsamfunnene nordpå. ${ }^{44}$

Til grunn for slike vurderinger ser det ut til å ha ligget en forventning om at samer og kvener så å si burde ha agert i tråd med sine 'objektive etniske interesser', en forventning som har preget særlig samisk historieskriving i Norge.

\footnotetext{
${ }^{40}$ K. J. Maliniemi, Arkivdokumentene forteller. To kommuner - to typer minoritetspolitikk, Oslo 2010.

${ }^{41}$ E. R. Hansen, Porsanger bygdebok, bind I, Lakselv 1986; A. Petterson, Småfolk og drivkrefter. Porsanger bygdebok bind II: Fra 1900 til 1960, Alta 1994. Jf. Ryymin og Maliniemi 2009: 134; Maliniemi $2010: 45$.

${ }^{42}$ Niemi og Salvesen 1987: 79.

${ }^{43}$ B. Aarseth, Norsk samepolitikk 1945-1990. Målsetting, virkemidler og resultater, Oslo 2006: 38-40.

${ }^{44}$ Niemi og Salvesen 1987: 82.
} 


\section{Fortellinger i samisk historie - assimilering og emansipasjon}

Forventningen om korrekt rettet, det vil si etnisk-basert, motstand var til stede allerede i pionerverket om samisk etnopolitisk mobilisering, Den samiske nasjon av sosiolog Per Otnes (1971). Otnes skrev programmatisk imot tidligere samfunnsvitenskapelig forskning, der samenes problemer med etnopolitisk organisering ble forklart med spredt bosetning, kommunikasjonsvansker, lite erfaring med organisasjonsarbeid og interessemotsetninger innen samefolket. Otnes mente at samene ikke var passive eller en tiltaksløs gruppe. Det var den norske staten, snarere enn individuelle egenskaper eller en særskilt samisk mentalitet, som hadde tvunget samene til passivitet - noe som forklarte vanskene med etnisk mobilisering. ${ }^{45}$ Otnes satte slik tonen for den første fasen av samisk forskning: Særlig sosialantropologene, som inspirerte historikerne i 1970-årene, har hatt en tendens å betrakte staten Norge som monolittisk og fremstille velferdsstaten som et problem med sine homogeniserende tendenser overfor minoritetsgrupper. I mye av den samfunnsvitenskapelige litteraturen om samiske forhold har man lagt et etnisk konfliktperspektiv til grunn for studier, og fra dette utgangspunktet har samene gjerne vært fremstilt som i forsvarsposisjon og sterkt akkulturerte. ${ }^{46}$ Denne samfunnsvitenskapelige fremstillingen var en grunn til at samisk historie fra 1970-årene var politisk sett like mye innrettet på å bygge motnarrativer om staten Norge som på å bygge en egen, emansipatorisk narrativ om samenes kamp.

Samenes historie i Norge ble i en rekke verk fra 1970- til 1990-årene fremstilt som en vanskelig kamp mot kulturell og politisk utradering ut fra en marginalisert og maktløs posisjon, for eksempel av historikerne Regnor Jernsletten og Henry Minde. Ifølge denne varianten av assimileringsplottet har den norske staten har tvunget samene til etnopolitisk passivitet ${ }^{47}$ og skam over egen etnisitet. ${ }^{48}$ Staten har stigmatisert samene som laverestående i forhold til nordmenn og dømt den samiske kulturen til døden gjennom fornorskning. Den norskinitierte moderniseringen av Nord-Norge har gjort samene til offer for den voksende kløften mellom folkeslag, og utsatt samene for den norske hverdagsrasismen. Samlet ledet dette til samisk defaitisme og den

\footnotetext{
${ }^{45}$ Minde 1992: 14-21; P. Otnes, Den samiske nasjon, Oslo 1970: 13, 17, et passim.

${ }^{46}$ Minde 1992: 8, 10-13; Otnes 1970: passim; H. Minde, The Post-War Sami Society in Norwegian Historiography. Paper presented to the First International Conference of Arctic Social Sciences, Université Laval, Ste-Foy, Quebéc, 1992: 2.

${ }^{47}$ R. Jernsletten, Samebevegelsen i Norge. Idé og strategi 1900-1940, Troms $\varnothing$ 1998: passim; E. Lorenz, Samefolket i historien, Oslo 1981: passim; H. Minde, Assimilation of the Sami - Implemention and Consequences, Acta Borealia 2003, 20: 123-124, 133-134; Niemi og Salvesen 1987: passim; Otnes 1970: passim.

${ }^{48}$ Minde 2003, 141-142.
} 
såkalte "fimbulvinteren" i mellomkrigsårene, under hvilken samene internaliserte den norske rasebaserte diskursen som dømte det samiske folket til undergang. ${ }^{49}$ Dette utgjør det samiske motnarrativet om staten Norge - et sluk der samisk identitet og kultur forsvinner.

Et sentralt element i denne fortellingen er hvordan den første samiske aktivitetsbølgen i de første tiår av 1900-tallet gikk mot sin undergang. ${ }^{50}$ Denne første fasen av samisk etnopolitisk mobilisering var dømt til å mislykkes, delvis på grunn av feil strategivalg og delvis på grunn av den overmektige fornorskningspolitikken. ${ }^{51}$ Men samtidig brukte både Jernsletten og Minde denne fortellingen som grunnlag for en ny fortelling om etterkrigstidens etnisk baserte kamp mot den norske staten. Statens rolle i fremstillingen var fortsatt den store undertrykkeren, før skiftet i den norske samepolitikken på 1980-tallet. ${ }^{52}$

Som i Den finske fare har historikere som har skrevet om samiske forhold, tradisjonelt fremstilt ytre press i form av spredning av ikke-samisk bosetting, fornorskningspolitikk samt den norske lovgivningens resultater angående rettigheter til land, vann og reindrift, som årsaken til samenes etniske mobilisering i Norge. Og i deler av den samiske forskningen lever en forventning om fullstendig opposisjon og konflikt mot den norske staten. ${ }^{53}$ Denne fremstillingen har ledet til et visst paradoks med den tilsynelatende komplette fornorskningen og den påfølgende etniske apatien blant samene. ${ }^{54}$ Men på andre måter enn i kvensk historie har forholdet til staten vært et av de mest avgjørende momenter for å kategorisere samisk etnisk mobilisering og i byggingen av en ny, emansipatorisk fortelling som vektlegger samenes vei til seier på nasjonale og internasjonale arenaer: De første kampårene 1904-1913 har blitt heroisert, mens "fimbulvinteren", det vil si de stille årene frem til 1940-tallet etter den første etniske aktivitetsbølgen, med den internaliserte troen på rasemessig undergang, har mindre potensiale for

\footnotetext{
${ }^{49}$ H. Minde, Diktning og historie om samene på Stuoranjárga, Rapport I, Skoddebergprosjektet, Kautokeino 2000: $171,173,176$.

${ }^{50}$ H. Minde, The Sami Movement, the Norwegian Labour Party and Sami Rights, bd. 2 i L'Image de L'Autre, Etrangers, Minoritaires, Marginaux, 16e Congrès International den Sciences Historiques, Stuttgart 1985, Sorbonne 1985: 405, 424.

${ }^{51}$ E. A. Drivenes og R. Jernsletten, Det gjenstridige Nord-Norge, Religi $\phi$ s, politisk og etnisk mobilisering 18501990, bd. 1 i E. A. Drivenes et al. (red.), Nordnorsk kulturhistorie, Det gjenstridige landet, Oslo 1994: 248-249; Jernsletten 1998: 128, 153-154.

${ }^{52}$ R. Jernsletten, The development of a Saami élite in Norden, i K. Karppi og J. Eriksson (red.), Conflict and Cooperation in the North, Umeå 2002, 152 ff.; Minde 1985: 410 et passim.

${ }^{53}$ Lorenz 1981: 92-95.

${ }^{54}$ F.eks. Jernsletten har en nyansert diskusjon om fornorskningen og etnopolitisk mobilisering. Jernsletten 1998: 4648, 54-58; Minde 1985: 423-424.
} 
akkurat det. ${ }^{55}$ Den resignerte, defaitistiske samiske politiske aktivisten fremstår som et eksempel på et uønsket valg av feil strategi, tatt på basis av fornorskningen. En slik fremstilling ga mening i lyset av etterkrigstidens samepolitiske utvikling, som rettet skarpe krav mot den norske staten, og den radikale norske samebevegelsens politikk i historikernes egen samtid. Fimbulvinteren blir fimbulvinteren bare sett i ettertid - og i sammenligning med den mer radikale samiske etnopolitikken i 1980-årene.

Den andre fasen i det dominerende emansipatoriske samehistoriske narrativet går ut på samiske aktivisters brudd med feil strategi til en "sann" etnisk mobilisering som tar utgangspunkt i samiske behov og virkelighet, og som viderefører kampen i den globale urfolksbevegelsens kontekst. Denne etterkrigsaktivismen, som bygde på fremtidsrettede, heroiske og romantiserende frigjøringsbilder, fremstår i forskningen som et eksempel på en korrekt, etnisk-basert handlingsstrategi. ${ }^{56}$ Ageringsrammene har dessuten blitt utvidet fra det nasjonale til det globale urfolksfellesskapet, der kampen om rettigheter fortsetter til dags dato. Erkjennelsen av samene som urfolk i Norge, i form av ratifiseringen av ILO-konvensjon nr. 169 i 1990, fungerer både som et sluttpunkt på en ny seiersfortelling og en mellometappe i en kontinuerlig rettighetskamp på den nasjonale og den globale arenaen. Historien om innføringen av Finnmarksloven i 2005 brukes som et eksempel i seiersfortellingen der staten Norge gir etter for internasjonalt press. ${ }^{57}$ Denne fortellingen fremstår som gyldig på bakgrunn av historiske forhold - for eksempel krav om å gi opp samisk identitet og kultur og de dokumenterte sterke sanksjoner i deler av samisk/norsk samfunn til langt ut på 1950-tallet, og tilsvarende samebevegelsens seire på 1980og 1990-tallet ${ }^{58}$ - men vi kan trygt konstatere at dette samiske narrativet har både en sosiopolitisk dimensjon og en emansipatorisk funksjon. ${ }^{59}$ Det har vært noen fors $\varnothing \mathrm{k}$ å forklare den defaitistiske

\footnotetext{
${ }^{55}$ Minde 2000: 205. Om begrepet "fimbulvinteren", introdusert av Hans J. Henriksen i 1965, se Jernsletten 1998: $142 \mathrm{ff}$.

${ }^{56}$ Jernsletten 1998: 28, 105 ff; Minde 1985: 405, 415, 418, 421-22, 426, 429 et passim; Minde 1992: 27 ff; Minde 2000: 155; Otnes var en foregangsmann også i denne sammenheng med sine anbefalinger om etableringen av samisk "nasjonal frigjøringsfront". Otnes 1970: 31; H. Salvesen, Makt og avmakt i samisk historie, i Årbok i Trøndelag, 1979: passim.

57 Om det globale, se H. Minde, The Challenge of Indegism: The Struggle for Sami Land Rights and SelfGovernment in Norway 1960-1990, i S. Jentoft, H. Minde og R. Nilsen (red.), Indigenous Peoples: Resource Management and Global Rights, Delft 2003: passim; H. Minde, The Alta case: From the local to the global and back again, i G. Cant et al. (red.), Discourses and Silences: Indigenous peoples, risks and resistance, Christchurch 2005: passim; H. Minde, The Destination and the Journey: Indigenous Peoples and the United Nations from the 1960s through 1985, i H. Minde (red.), Indigenous Peoples, Self-Determination, Knowledge, Indigeneity, Delft 2008: passim.

${ }_{58}$ Drivenes og Jernsletten 1994: 262-263.

${ }^{59}$ J. Elliot, Using Narrative in Social Research, Qualitative and Quantitative Approaches, London 2005: 50.
} 
og fornorskede same med hensyn til forskjellige rasjonalitet og strategier, ${ }^{60}$ men det er dette emansipatoriske narrativet, som stigmatiserer andre slags holdninger mot staten og konkurrerende aktører innom samebevegelsen, som åpenbart har preget tekster om samisk (etno)politikk fra 1970-årene til 1990-tallet. I dette fortellingsmønsteret blir den moderate same dels et forstyrrende element på samenes vei til nasjonal og internasjonal seier, dels en underkommunisert utfordring.

\section{Agens fremfor assimilering?}

En historieskriving som primært fokuserer på handlingen og valgene til de mennesker som ellers kan la seg kategorisere som tilhørende ulike etniske grupper, vil vi i denne sammenhengen betegne som agenstradisjonen. Handlingene det fokuseres på kan dreie seg både om strategier for å unngå eller unndra seg assimilering på ulike måter eller tvert om fokusere på integrasjonsbestrebelser, språkskifte eller andre slike handlingsmønstre. Ett eksempel som riktignok faller utenfor denne artikkelens tematiske fokus, men som var med på å etablere agensperspektivet i samisk historie, er oversiktsverket Samenes historie fram til 1750, av historikeren Lars Ivar Hansen og arkeologen Bjørnar Olsen. De skrev programmatisk imot de rådende fortellingene om det ublide møtet mellom et homogent, statisk samisk samfunn og modernitet og markedsøkonomi. Hansen og Olsen ville løfte frem foranderlighet og endring i samisk historie gjennom å fokusere på samspillet mellom eksterne krefter og interne prosesser, og følgelig se samene som aktører i et kulturbytte. ${ }^{61}$ Verket presenterte en måte å betrakte samene som del av ulike nettverk og som aktive historiske agenter, en innfallsvinkel som i lengre tid hadde vært fremhevet som ønskelig i det samiske forskningsmiljøet, i opposisjon mot forskning med essensialiserende assimileringsnarrativer som utgangspunkt.

Historieskriving med et utgangspunkt i agenstradisjonen har ikke vært like fremtredende eller dominerende som assimileringstradisjonen, men eksempler finnes. I stedet for å forklare både opphavet og hensovningen av den første samiske etnopolitiske mobiliseringsfasen med fornorskningspolitikken, har Henry Minde diskutert den samiske mobiliseringens dynamikk i lys av intra-samisk identitetsforvaltning. I boken Diktning og historie om samene på Stuoranjárga (2000) gransket Minde samisk aktørskap mellom to kulturelle ordener, den samiske og den norske, der samiske aktivister opererte. Han unders $\varnothing$ kte aktivistenes livskarrierer og ideologien

\footnotetext{
${ }^{60}$ F.eks. Drivenes og Jernsletten 1994: 250-253, 262; Jernsletten 1998; Minde 2003: 140.

${ }^{61}$ Hansen og Olsen 2004: 14-16.
} 
rundt det samiske i forhold til interne normer og tradisjoner i de to lokale ordener, og hvordan deres påvirkning resulterte i en resignert samisk bevegelse som primært tok sikte på å vise samisk identitet i den private sfæren. Selv om Minde fokuserer på elementer som ikke ledet til mobilisering, fremstiller han ikke de samiske aktørene som ofre, men som politiske aktører in spe, - eller som et eksperiment før den fulle blomstringen av etnopolitikken, som Regnor Jernsletten formulerer det - mens han samtidig gir statens ideologiske hegemoni sin fortjente del i forklaringen. ${ }^{62}$

Et annet eksempel på fremstillinger der minoriteters agens står sentralt, er historikeren Jukka Nyyssönens doktoravhandling fra 2007, "Everybody recognized that we were not white": Sami identity politics in Finland, 1945-2000. Nyyssönen undersøker finske samiske aktørers etno- og næringspolitiske strategier uten på forhånd å ha bestemt seg for at en bestemt handlingsmåte er mest "riktig" for aktørene; snarere forsøker han å historisere de valg som samiske aktivister i Finland i tiårene etter krigen tok, ut fra deres egne forutsetninger. Nyyssönen viser at samiske aktører i Nord-Finland gikk aktivt inn for modernisering av landsdelen - som en samisk strategi. I assimileringstradisjonen fremstilles vanligvis nettopp moderniseringsprosessen som en nokså sikker vei til tap av samisk identitet.

Synliggjørings- og særlig assimileringstradisjonen bygget på en relativt fasttømret forståelse av hvem de etniske minoritetene var, til tider i form av en strategisk essensialisme: For å kunne fungere som grunnlag for styrking av etniske kollektivers rettigheter, måtte kollektivene fremstilles som nokså enhetlige eller homogene. ${ }^{63}$ Agens-orientert minoritetshistorie er gjerne mer opptatt av måten de etniske kategoriene historisk har blitt til, og hvordan de har endret seg. Fremfor å legge til grunn en bestemt forståelse av for eksempel kvenskhet eller samiskhet, og deretter plassere individer i denne kategorien og/eller st $\varnothing$ tte opp under etnopolitiske, historisk funderte krav på vegne av en etnisk kategori, gjøres nettopp produksjonen av etniske kategorier og kjennetegn, og deres relasjoner til politiske posisjoner, til gjenstand for historisk analyse i slike arbeid. ${ }^{64}$ Slike perspektiver er i ferd med å bli vanligere også i historieskriving om kvenene: I historikeren Lena Aarekols doktoravhandling fra 2009, Kvenske minnesteder 1970-2001.

\footnotetext{
${ }^{62}$ Jernsletten 1998: 2, 142-148; Minde 2000: 136-156.

${ }^{63}$ Om "strategisk essensialisme" se G. C. Spivak, Subaltern Studies: Deconstructing Historiography, i In Other Worlds. Essays in Cultural Politics, New York 1988: 197-221.

${ }^{64}$ Se for eksempel T. Ryymin, Creating Kvenness: Identity building among the Arctic Finns in Northern Norway, Acta Borealia 2001, 1: 51-67; T. Ryymin, The Making of an Ethnic Identity: From Finns to Kvens, i M. Lamberg (red.), Shaping Ethnic Identities: Ethnic Minorities in Northern and East Central European States and Communities, c. 1450-2000, Helsinki 2007: 100-157.
} 
Materialitet og minne, undersøkes hvordan en rekke aktører - med og uten kvensk bakgrunn har vært med på å skape og forme ulike symboler og minnesteder gjennom en prosess Aarekol betegner som "kvenifisering": Symboler som Innvandrermonumentet i Vads $\varnothing$, reist i 1977 som et minne over den finske innvandringen til Finnmark på 1700- og 1800-tallet, har gradvis blitt byttet ut med symboler som står for kvenskhet - i Aarekols avhandling eksemplifisert med kvendrakten, ferdigstilt i 2001. ${ }^{65}$ Også Maliniemis analyse av minoritetsspråklige arkivdokumenter fra Finnmark vektlegger nettopp kategoriseringsprosesser i arkivsammenheng. ${ }^{66}$

En konsekvens av slike konstruktivistiske tilnærminger er imidlertid at de ikke har noen entydige politiske funksjoner. På den andre siden kan slike konstruktivistiske perspektiver tenkes å reflektere bedre det (etno)politiske mangfoldet i samiske (og kvenske) samfunn. Sameparlamentenes etnopolitiske strategier som har siktet mot ratifiseringen og bruk av internasjonale konvensjoner av urfolksrettigheter, har møtt intern kritikk i det siste i Finland. ${ }^{67}$

Dersom et rendyrket agensperspektiv fører til en neglisjering av handlingers historiske kontekster og rammer, kan dette føre til en undervurdering av de strukturelle, asymmetriske historiske maktrelasjoner mellom minoriteter og majoriteten, og overvurdere minoritetenes makt og agens i valg av strategier. Lignende problem mellom historiske tilnærminger som vektlegger henholdsvis strukturelle forhold og agens/identitet er grundig diskutert innen kvinne- og kjønnshistorien alt fra 1980-årene, uten at noen entydige veier ut av dette problemet er presentert. ${ }^{68}$ Generelt må agens alltid sees i kontekst, og de historiske rammene for valg må erkjennes - men ikke på en måte som a priori fratar minoritetene mulighet for handling. På den andre siden må også assimileringspresset vurderes historisk og kontekstuelt, med øye på forskjellige generasjonserfaringer og variasjon i tid og rom, for å avdekke dens fulle historiske betydning.

De ulike fortellingsmønstrene skissert ovenfor $\quad-$ synliggjøringstradisjonen, assimileringstradisjonen og agenstradisjonen - må ikke forstås som suksessive faser som avløser hverandre i retning av stadig mer avansert eller bedre historieskriving. Snarere er fortellingsmønstrene blitt etablert lag på lag eller side om side med hverandre, slik at det

\footnotetext{
${ }^{65}$ L. Aarekol, Kvenske minnesteder 1970-2001. Materialitet og minne. Phd-avhandling, Universitetet i Troms $\emptyset$ 2009.

${ }^{66}$ Se for eksempel Maliniemi 2010: 33-36, 59-60, 100-106.

${ }^{67}$ S. Valkonen, Poliittinen saamelaisuus, Tampere 2008: passim.

${ }^{68}$ Jf. G. Hagemann, Feminisme og historieskriving. Inntrykk fra en reise, Oslo 2003: 75-90; I. Blom, Mentalitetshistorie og kvindehistorie, i I. Frederiksen og H. Rømer (red.), Kvinder, mentalitet, arbejde.

Kvindehistorisk forskning i Norden. Rapport fra det 2. nordiske kvindehistoriemøde 1985, Aarhus 1986: 14-26.
} 
minoritetshistoriske feltet fremstår i 2011 som mer mangfoldig, eller fragmentert, sammenlignet med 1970-årene. For eksempel knyttet samiske historikere assimileringsfortellingen til et synliggjørende program som siktet mot å omdefinere den enhetlige og etnisk homogene nasjonalstaten Norge i sin forskning fra 1970 -tallet og utover. ${ }^{69}$ Og historieskriving som primært tar sikte på synliggjøring er stadig relevant innenfor kvenhistorien - men i nye varianter, og $\mathrm{i}$ kombinasjon med andre fortellingstradisjoner. Den tidligere omtalte arkivstudien av Kaisa Maliniemi, som løfter frem kvenenes (og samenes) aktive rolle i lokalforvaltningen i Finnmark, er ett eksempel på historieskriving som kombinerer et synliggjøringsplott med vektlegging av minoriteters agens, eller som det eksplisitt skrives i verkets avslutning: "(...) samer og kvener [var] ikke (...) så tause og usynlige som man i ettertid har trodd. De har på lokalt hold vært aktivt med på fellesskapets forskjellige områder. Tause stemmer var ikke så tause likevel." ${ }^{, 70}$ Et annet eksempel er boken Den finske arven. En antologi om det finske Finnmark, utgitt av Nord-finsk forbund i 2009. Bokens første del, "Fra Finland til fremtidslandet Ruija", synliggjør folkegruppens vandring til Nord-Norge. Den følgende delen ("Den finske påvirkningen") diskuterer emigrantenes bidrag på ulike felt i Finnmark, mens den siste delen peker fremover, til "Den finske fremtid i Norge". Den narrative strukturen i Den finske arven er med andre ord ganske lik de tekstene som dominerte kvensk historie i 1970-årene; et ytterligere likhetstrekk er bruken av "finne" eller "norskfinne" som kategori på emigrantene. Boken har et tydelig agg mot bruken av kategorien "kven" om disse migrantene, som ble vanlig i 1980- og 1990-tallets historieskriving: Forfatterne hevder at bruken av "kven" usynliggjør "det finske og norskfinske" i fortiden, samt skaper en (utilbørlig) kontinuitet mellom middelalderens kvener i Bottenviken og de samtidige norske "kvenene". Den "kvenbaserte" historien karakteriseres også som politisert elendighetshistorie som primært sies å ha fungert som et utgangspunkt for etnopolitiske krav rettet mot myndighetene. ${ }^{71}$ Mot dette fremheves "norskfinnenes" vellykkede integrasjon i det nordnorske samfunnet, slik forfatteren Morten Thuv gjør det under tittelen "Velstand, ikke elendighet":

Finnene og norskfinnene tok altså det norske klengenavnet, kven, til etterretning, men aksepterte det aldri som sitt eget. De fortsatte helhjertet og upåvirket etableringen og integreringen her i Norge. Generasjoner kom og gikk mens små og store samfunn oppstod av pågangsmot, hardt arbeid og finsk sisu. Mange bygder og Vads $\varnothing$, finnenes hovedstad i Norge (...) er tuftet på finsk innvandring. Store deler av Ruija måtte

\footnotetext{
${ }^{69}$ Hansen og Olsen 2004: 13-14.

${ }^{70}$ Maliniemi 2010: 113.

${ }^{71}$ Se særlig Morten Thuvs bidrag i boken, T. Robertsen (red.), Den finske arven. En antologi om det finske Finnmark, Vadsø 2009: 205-222.
} 
gjenreises etter den andre verdenskrigen, noe norskfinnene tok sin del i og formet den moderne tid de neste tiårene. Som ellers i landet og i nabolandene, forlot man sakte men sikkert den gamle bondekulturen. (...) De finske innvandrernes pågangsmot har utviklet seg til moderne gründervirksomhet i stor skala. ${ }^{72}$

Synliggjøringen av kategoriene "finner" og "norskfinner", og vektleggingen av integrasjon, fungerer her som motfortellinger mot tidligere fortellinger om kvenenes historie. Slik sett er Den finske arven et godt eksempel på hvordan den mangfoldige minoritetshistorien stadig genererer sine egne motnarrativer.

At representanter for ulike minoriteter går i bresjen for en ny historieskriving, er ikke enestående. Hva slags perspektiv fortiden til en etnisk gruppe skal sees i, og hvordan den skal fortelles om, er også et politisk spørsmål, og dermed vil ulike aktører med ulike, mer eller mindre eksplisitte politiske mål, ha forskjellige meninger om historiens innretning. Sosiologen Rune Halvorsen har påpekt at representanter for romanifolket i Norge har fremstilt sin historie som en fortelling om elendighet og undertrykking, og gruppen er ettertrykkelig plassert $\mathrm{i}$ en offerposisjon. ${ }^{73}$ Ifølge Halvorsen har denne historiefremstillingen ført til gjennomslag for enkelte politiske mål og generert ulike former for støtte - men samtidig har denne tilnærmingen til romanifolkets fortid vanskeliggjort andre politiske prosjekt. Det har fått andre aktører til å vektlegge positive sider ved romanifolkets historie, blant annet dets rike kulturelle arv. Funksjonen til disse fortellingene har vært å styrke gruppens positive selvbilde, på samme måte som de tidlige 1970-tallsarbeidene om kvenenes historie potensielt var med på å gjøre det.

\section{Norsk minoritetshistorie, Aboriginal history og New Indian History}

Sammenlignes norsk minoritetshistorie om samer og kvener med urfolkshistorie skrevet i Australia og USA, fremtrer en rekke paralleller. For det første var det historiografiske utgangspunktet for etableringen av disse sjangrene lignende: Urfolk var glemt i eldre fremstillinger av de nasjonale historier, eller underkommunisert i fortellinger om fremskritt og sivilisasjon. I australsk historieskriving ble urfolk representert som ute av stand til selv å besitte og skape historie. Den rådende tilnærmingen til australsk historie var rasebasert, i form av såkalt "historicism" som bygget på europeiske ideer og idealer om historisk forandring, og på et

\footnotetext{
${ }^{72}$ M. Thuv, Fra svedjebruk til etnopolitisk ulmebrann, i T. Robertsen (red.), Den finske arven. En antologi om det finske Finnmark, Vadsø 2009: 222.

${ }_{73}^{73}$. Halvorsen, Taternes arbeid for oppreisning og anerkjennelse i Norge, Trondheim 2004: 31-37, 73-74.
} 
sosialdarwinistisk influert syn på aboriginale som et utdøende folkeslag som manglet begreper om eiendom og hadde ingen legitim tilhørighet $i$ en moderne stat. ${ }^{74}$

Særlig fra 1930-årene ble de voldelige aspekter ved møtet mellom urfolk og settlere i Australia underkommunisert. Når denne stillheten ble brutt av historikere på 1960- og 1970-tallet, ble den rådende mesterfortellingen om fremskritt og samlingen av en nasjon kraftig revidert. Som i Norge, var denne revisjonen inspirert av nye sosialhistoriske impulser. Men i Australia ble urfolks agens fokusert på alt i 1980-årene, som i Henry Reynolds’ The Other Side of the Frontier (1981), hvor målet var å undersøke urfolks erfaringer av og ageringsmåter i frontier-konflikten. Fremveksten av urfolkshistorien ga de nasjonale historier nye temaer, problemstillinger, agenter, kronologier og kategorier, blant dem kolonialisme: I tillegg til bosetting, skrev man nå også om invasjon. Kategorier som «pre-invasion history» og «aboriginal culture» ble integrert i de nasjonale historier, gjerne kategorisert som Australias «deep past» eller «deep time».

I tillegg til utgangspunktet - underkommunikasjonen av minoriteter - var også behovet for demokratiseringen av historisk gransking, synliggjøring og revisjon av urfolkshistorie og et nytt, kritisk blikk på statsdanning felles for etableringen av urfolkshistorien i Australia og minoritetshistorieskrivingen i Norge. I begge land har historieskrivingen om minoriteter også endret seg i løpet av de siste tiår, ved at oppmerksomheten på minoriteters agens og tilpassing og samarbeid i det historiske møtet mellom urfolk og bosettere har vokst. I Australia gjelder dette særlig for historieskriving som ensidig har fokusert på "frontier violence"; i Norge kan vi se på nyanseringen av assimileringsfortellingen som en tilsvarende historiografisk tendens. ${ }^{75}$

Likevel utgjør særlig graden av radikalitet en forskjell mellom norsk minoritets- og australsk urfolkshistorie. Kolonialisme som historisk element i nordisk sammenheng har ikke den naturlige resonans den har i historier om settler-states. Det samme gjelder det historiske fundamentet til krav om urfolks rettigheter, der det i nordisk kontekst jo ikke finnes noe klart tidspunkt for kolonisering. Også fremstillingen av aboriginaler i australsk historiografi har vært mer radikal enn i Norge - både før og etter etableringen av urfolkshistorieskrivingen. I eldre australsk historieskriving var de britiske emigranter de selvsagte hovedaktører, og aboriginaler ble tilskrevet alle de egenskaper som britene stod som motsats til: Aboriginaler var brutale

\footnotetext{
${ }^{74}$ B. Attwood, Rights for Aborigines, Crows Nest 2003: xi.

${ }^{75}$ B. Attwood, Telling the Truth about Aboriginal History, Crows Nest 2005: 14-19, 22-23, 37-41; M. Nugent, Botany Bay. Where Histories Meet, Crows Nest 2005: 24-25, 27; H. Reynolds, The Other Side of the Frontier. Aboriginal resistance to the European invasion of Australia, rev. ed., Sydney 2006.
} 
villmenn som ikke dyrket landet, manglet lov og andre institusjoner, som var få og i ferd med å forsvinne som menneskerase, som det regressive folkeslaget de var. Settlerstyret hadde møtt dem med velvilje og gavmildhet, som i beskyttelse gjennom britisk lov og innføringen av kristendom. $^{76}$

Brutaliteten i den historiske koloniseringen og de rasebaserte tilnærmingene i majoritetshistoriene ledet til at motfortellingen - urfolkshistorien - ble minst like aggressiv. Aboriginal history, dannet på midten av 1970-tallet og i perioder dominert av aboriginale historikere, har delvis hatt radikale utgangspunkt i sin omskrivning av deres historie. Dette gjelder for eksempel i forhold til lineær tid, som ble bortkastet: Fortiden er til stede i samtiden så vel som fremtiden, den konstituerer aboriginale identiteter og forteller hvor mennesker kommer fra og hvem de er. Den identitetsdannende funksjonen til Aboriginal history har vært mer eksplisitt enn i den norske minoritetshistorien og gitt den en bevisst personlig og innsnevret preg: Historiene er ofte historier om historikeres egne eller den nære slektens erfaringer - noen ganger i form av en myte eller en legende, fortalt til deres egne folk og formidlet gjennom flere kanaler enn bare akademisk historieskriving. ${ }^{77}$

I USA har interdisiplinær ethnohistory, som opererer i skjæringsfeltet mellom antropologi og historie, lange tradisjoner. I utgangspunktet var etnohistorie opptatt av "primitive" folkeslag, med mål om å forstå kulturer som helhet, ut fra deres egne premisser. Etnohistorien har likevel utviklet seg fra paternalistiske beskrivelser av urfolk som passive, rigide objekter og primitive folkeslag ved hjelp av kildene produsert av kolonistene, til analyser som vektlegger urfolks rolle, erfaringer, initiativer og rasjonaliteter $\mathrm{i}$ det koloniale møtet. Kravet om bruk av andre kildekategorier, gjerne produsert av urfolk selv, ble i 1960-årene fremmet med styrke av utøvere av det såkalte New Indian History. Tendensen til en mer relasjonell tilnærmingsmåte og agensfortellinger fant også sted i 1960-årene, altså langt tidligere enn i Norge. Mange etnohistorikere var frustrert over den dominerende måten å skrive om indianernes historie på, med vekt på føderal politikk rettet mot indianerne. ${ }^{78}$

\footnotetext{
${ }^{76}$ Attwood 2005: 15-16.

77 Attwood 2003: xii; Attwood 2005: 42-47. Et eksempel på dette er Nugent 2005.

${ }^{78}$ J. Axtell, The Ethnohistory of Native America, i D. L. Fixico (red.), Rethinking American Indian History, Albuquerque 1997: 11, 13-15, 20; A. Beck Kahoe, The Ghost Dance. Ethnohistory and Revitalization, Holt 1989; W. T. Hagan, The New Indian History, i Fixico 1997: 29-40; R. Wright, Stolen Continents. The "New World" Through Indian Eyes, Boston og New York 1992.
} 
Selv om målet med å løfte frem urfolks agens ble artikulert tidlig, hevdes det fortsatt at dette målet ennå ikke er nådd i tilstrekkelig grad. Flere amerikanske historikere med urfolksbakgrunn har uttrykt sterk misnøye både med neglisjeringen av muntlige kilder og dermed urfolksperspektiv i New Indian History, og med forskningens manglende nytte i «empowerment» og avkolonisering av stammene. Et forvrengt og feilaktig bilde gjentas fortsatt i repetitive representasjoner, hevdes det, og forskere utfordrer også det epistemologiske fundamentet i «vestlige paradigmer» som stempler muntlige kilder som upålitelige og anser politiske målsettinger i forskning som uønsket. Postkolonialt inspirerte forskere reiser også kompliserte forskningsetiske og forskningspolitiske problemstillinger om hvem har rett å utøve "Indian History” og på hvilke måter. Feltet varierer i sin eksklusivitet og epistemologisk "renhet”, men er for det meste samlet i misnøyen med sin marginaliserte posisjon i akademia, med de mislykkede og feilaktige fremstillinger av urfolk, skrevet for det meste av hvite menn, og som primært gagner forskeren selv. $^{79}$

Sammenlignes norsk minoritetshistorieskriving med Aboriginal history og New Indian History, kan to ting påpekes: Det tidligere fokuset på urfolks agens og større grad av epistemologisk radikalitet blant urfolkshistorikere i USA og Australia. At urfolks agens ble tidlig løftet frem på den minoritetshistoriske forskningsagendaen i disse land, understreker den banebrytende karakteren til Den finske fare i norsk sammenheng: Det fantes ikke forskning som hadde problematisert den norske minoritetspolitikken fra det perspektivet dette verket gjorde, mens tematikken alt var grundig belyst i USA. Behovet for å nyansere samisk og kvensk agens har i Norge oppstått i etterkant. For det andre er de australske og amerikanske urfolkshistoriske motnarrativer både epistemologisk og forskningspolitisk mer radikale enn deres norske paralleller. Selv om assimilasjonsfortellingen har blitt brukt på mange akademiske felt som empirisk grunnlag i postkolonialt inspirert forskning, er radikal postkolonial historieskriving fraværende $\mathrm{i}$ Norge. Allment har postkoloniale perspektiver så langt vært fraværende i norsk akademisk historieskriving, og det første minoritetshistoriske arbeidet som virkelig utfordret den norske nasjonale mesterfortellingen, Den finske fare, var trygt basert på «vestlige paradigmer» for historieforskning og ga ingen anstøt til kunnskapsteoretisk mer radikale tilnærminger til

\footnotetext{
${ }^{79}$ D. A. Mihesuah, Introduction, i D. A. Mihesuah (red.), Natives and Academics. Researching and Writing about American Indians, Lincoln og London 1998; D. A. Mihesuah, Should American Indian History Remain a Field of Study?, i D. A. Mihesuah og A. Cavender Wilson (red.), Indigenizing the Academy. Transforming Scholarship and Empowering Communities, Lincoln og London 1998; W. A. Cavender, American Indian History or Non-Indian Perceptions of American American Indian History?, i Mihesuah 1998.
} 
minoritetshistorien. Også identitetspolitisk virker ideene om nordisk kolonialisme - og nordisk post-kolonialisme - heller fjerne som grunnlag for minoritetshistorien i en norsk sammenheng.

Den australske nasjonale mesterfortellingen som senere urfolkshistorie posisjonerte seg i forhold til, hadde to hovedelementer: For det første, en seiersfortelling om fremskritt og sivilisering, uttrykt i etableringen av en egalitær britisk statsenhet, med australske elementer (mateship) som utdypet egaliteten. For den andre bar denne fortellingen et sterkt preg av å fremstille settlerne som ofre for vansker og lidelser knyttet til bosetting i en fremmed verdensdel, kjempende både for nytt land og et mer egalitært samfunn i en ny verden mot imperiets sentrum. ${ }^{80}$ Behovet for å etablere en mesterfortelling for den koloniale staten var sterk, og den tok form av komprimert mytedannelse der bevarelse av "den historiske sannhet" ikke nødvendigvis var hovedmålet. Fortellingene om Australia har skjult mer rasistisk vold, og en historie av dypere (etnisk) konflikt, enn det som har vært tilfellet i Norden: Historikerne tok den pedagogiske oppgaven med å legitimere transformasjonen fra de facto voldelig maktkapring fra urfolk til de jure autoritet og legitimitet ved å underkommunisere og forenkle nasjonens historie. Måten urfolkshistorikere fokuserte på urfolks lidelser satte spørsmålstegn ved begge hovedelementene i den australske nasjonale mesterfortellingen, fremskritt så vel som settlernes og Australias offerrolle. I Australia har statsmakten funnet mye bruk av fortellinger produsert av historikere; dermed har også konfliktene over forvaltning og produksjon av nasjonale fortellinger og historier vært dypere. De såkalte historiekrigene ("History Wars") dreier seg i høy grad om hvilken kategori av stater Australia skulle passe: Den siviliserte Vesten eller land med brutale historier i omgang med minoriteter, som Sør-Afrika. I Australia står selve statens vesen på spill i større grad enn for eksempel i Norge, der staten - og historikerne - kan lene seg tilbake på en lengre historie om kontinuitet i institusjonsbygging, løsrivelse fra de nordiske småskalaimperiene og bygging av velferdssamfunn. ${ }^{81}$

\section{Avsluttende bemerkninger}

Der finnes åpenbart noen dominerende fortellingsmønstre i historieskrivingen om samene og kvenene etter 1970. Mens historieskrivingen om kvenene i dette tiåret synliggjorde minoritetene,

\footnotetext{
${ }^{80}$ Attwood 2005: 14-16; se også Nugent 2005: 22-24, som identifiserer «Discovery» og «Convictism» som de to elementer i hovedfortellingen. Kaptein Cooks «oppdagelse» av Botany Bay i 1770 har blitt feiret som fødselen av den australske nasjon, mens «convictism» har sin plass i hovedfortellingen som den vanskelige fasen i Australias historie som man måtte komme seg gjennom på vei mot nasjonal storhet og sivilisasjon.

${ }^{81}$ Jf. Attwood 2005: 12-15.
} 
vektla 1980-årenes historieskriving de nordlige minoritetenes undertrykte offerposisjon, ut fra en erkjent emansipatorisk intensjon. En nyere tendens ser ut til å vektlegge det interne mangfold innen minoritetsgruppene, gruppenes relasjoner til andre og konstruksjonen av etniske identitetsmarkører.

Felles for de dominerende fortellingene både innen samisk og kvensk historie har vært rollen den norske staten tilskrives i minoritetenes "riktige", det vil si etnisk-funderte, agering: Det sterke assimileringspresset - skapt av statlig fornorsknings- og/eller velferdspolitikk - har vært det avgjørende. Det emansipatoriske samiske narrativet bygde på dette premisset allerede i det progressive 1970-tallet, mens det var i 1980-årene at denne fortellingen ble grundig etablert i kvensk historie. Fortellingen om de nordlige minoritetene som fornorskningspolitikkens ofre, som har fått gjennomslagskraft også langt utenfor historiefagets tekster, er paradoksal i dens insistering på nettopp fornorskningens totale virkninger - eksemplifisert gjennom fremstillinger av fornorskningen som "ei form for språklig og kulturell lobotomi som ramma alle som ikkje hadde norsk som morsmål eller førstespråk" ${ }^{\prime 22}$ - og forventningen om etnisk-basert handling som det mest riktige handlingsalternativet for samer og kvener, med den lammende fornorskningen som mobiliseringens fundament.

Gjennom etableringen av kvenene og samene som gjenstand for historieskriving, skrev historikerne den analytiske kategorien "etnisitet" inn i fortiden som en historisk realitet, på samme måte som kvinnehistorien gjorde det først med kategorien "kvinner", og deretter med kategorien "kjønn". Synliggjøringsplottet forutsatte at der fantes noe bestandig å vise frem. På en måte fungerte denne tilnærmingen dermed også som en produksjon av kategorier som fortiden ble grepet med og forstått gjennom, og 1970-årenes etniske revolusjon i den nordnorske lokalhistorien produserte etnisitet som et relevant skille mellom mennesker i fortiden. En konsekvens av dette var en intensivert leting etter samer og kvener i fortiden, en leting som i det minste i ettertid ble formulert som et normativt utgangspunkt: "I motsetning til tidligere, vil det nå være umulig ikke å tillegge samisk og kvensk historie vekt i fremstillinger for de aktuelle områder av landsdelen", skrev Einar Niemi i 1987 om den etniske historiens plass i nordnorsk lokalhistorie. ${ }^{83}$ Slik sett løp den oppvurderende og den synliggjørende funksjonen sammen i et etnisk imperativ for historieskrivingen.

\footnotetext{
${ }^{82}$ Bull og Gaski 1994: 246.

${ }^{83}$ E. Niemi, Nord-norsk lokalhistorie - kulturaktivitet, vitenskap og politisk redskap, Heimen 1987, 2, XXIV: 69-70.
} 
Dette etniske imperativet hadde en rekke konsekvenser. I mange tekster ser det ut til å ha innebåret en implisitt vurderingsmodell for fortidige menneskers handlinger: Samer og kvener burde ha agert i historien som samer og kvener, ut fra sine "objektive interesser" som tilhørende slike etniske kategorier. Hvis ikke, tolket historikerne dette nærmest som at folk handlet ut fra "falsk bevissthet", uten å erkjenne sine egentlige (etniske) interesser. Dette ligner på marxistisk strukturalistisk analyse, mutatis mutandis: I stedet for plassering i produksjonsforhold og objektive klasseinteresser, tok analysen utgangspunkt i "etniske" interesser som fortidens mennesker objektivt sett burde ha agert i tråd med. En slik vurderingsmålestokk i forskningen må selvsagt problematiseres - for når definerte etniske interesser blir gjort til målestokken som minoritetenes handling vurderes i forhold til, kan historisk analyse bli ahistorisk. Det etniske imperativet anerkjenner ikke andre handlingsstrategier, ei heller det faktiske mangfoldet og samspillet mellom mennesker uavhengig av hvordan de kan bli plassert, eller plasserer seg, i ulike etniske kategorier.

Avslutningsvis vil vi legge frem noen tanker om hvordan historieskrivingen om de nordlige minoriteter kan utvikles videre. Vi avviser ikke realitetene i fornorskningspolitikken, og nedvurderer heller ikke den samepolitiske bevegelsens betydning. Men gjennom å sette søkelyset på noen av de fortellingene som har vært dominerende i norsk minoritetshistorie, ønsker vi å skape et mulighetsrom for andre fortellinger, som blant annet kan se på etnisk-basert handling som ett blant flere historiske handlingsalternativer; andre handle- og identifikasjonsmåter må få fremtre på sine egne premisser, ikke målt opp mot en "objektiv" etnopolitisk mal som a priori anses som det mest gyldige handlingsalternativet for samer og kvener. Ved å legge et agensorientert perspektiv til grunn, kan vi flytte oppmerksomheten over på produksjon av subjekter og vise historisk hvordan mennesker blir til kvener og samer, i tilslutning til det siste tiårs agensbaserte fortellinger. Slik sett ønsker vi, i likhet med Bjørnar Olsen og Lars Ivar Hansen, å flytte oppmerksomheten fra etno- til identitetspolitikk, og fra kartleggingen av etniske essenser til studier av relasjoner. ${ }^{84}$ I stedet for - eller i tillegg til - å vise grunnleggende forskjeller, kan vi spørre hvordan slike "grunnleggende forskjeller" har blitt produsert historisk - av historikere og andre.

\footnotetext{
${ }^{84}$ Om relasjonell tilnærming, se L. I. Hansen og B. Olsen, Samenes historie fram til 1750, Oslo 2004: passim; L. I. Hansen, Samene i lokalhistorien: Utfordringer og erfaringer, Heimen 2010, 4, XLVII: 321-324.
} 
En historieskriving som legger til grunn et agensperspektiv, og som ønsker å historisere og dekonstruere etniske kategorier, vil møte visse utfordringer. Forskningsmessig vil en utfordring være å ha redskaper til å avgrense studieobjektene - om en avviser etniske kategorier som redskaper i utgangspunktet, hvordan skal man vite hvem skal man se på? En mulig løsning på dette er ikke å avsverge all kategori-tenkning, men snarere å bevege seg fra strategisk til pragmatisk essensialisme - det vil si, å avvise at en bestemt etnisitet bør følges av et bestemt handlingsmønster. ${ }^{85}$ En slik posisjon er uten den strategiske essensialismens politiske implikasjoner - men har selvsagt forskningsstrategiske konsekvenser. En annen mulighet er områdestudier der man ser på interaksjonen mellom folk i bestemte geografiske kontekster - der etnisitet kan være én relevant analytisk kategori blant andre: Hvordan agerte finskspråklige kommunister, læstadianere og andre i det nordlige Skandinavia på første del av 1900-tallet, og hvilken betydning hadde de etniske identitetsgrenser i slik interaksjon? I et slikt perspektiv er også lokal aktivitet, integrasjon og samhandling relevant å trekke inn, i tillegg til de statlige assimileringstiltak. Kanskje var stortingsrepresentantene Aksel Konrad Mikkola og Isak Saba ikke bare hjelpeløse ofre i fornorskningspolitikkens slagskygge, men også tydelige tegn på at de nordlige minoriteter var tett innvevd i det norske samfunnet på første del av 1900-tallet.

\footnotetext{
${ }^{85}$ Jf. Ryymin 2007: 106.
} 